\title{
ANAESTHESIA FOR TRANSSPHENOIDAL HYPOPHYSECTOMY *
}

\section{I $\mathbb{P}$ Brunelle, $M D$, and $C$ Lepage, $M$}

THE PROBL EMS OF anaesthesia for hypophysectomy depend on the surgical procedure carried out The intracianial subfrontal approach is the surgical technique most generally employed by neurosurgeons and the main problem encountered by the anaesthetist is oedema of the brani It is worth while to mention that causes conducive to reactive tissue swelling and productive of the clinical complications of cerebral oedema are various, including disconnection of venous dranage followed by elevation of the frontal lobe, pubarachnoid oozing of blood, ischaemia of the nervous tissue secondary to long standing retraction We must remind ourselves that these events can be in part prevented by using accessory methods which increase the intracranial chamber by reducing the brain volume, such as lumbar dramage of the CSF and ventricular puncture and aspuation of the fluid from the ventricle In some cases of pituitary tumour with suprasellar extension, hypothermia is utilized for damping the vegetative reactions of hypothalamic origin When, for particular reasons, hypotension is demanded by the surgeon, he should always be warned that the slightest pressure applied to the brain tissue by an instrument is liable to produce severe contusion and even an infarct of the whole frontal lobe ${ }^{1}$ Coughing, vomiting, anoxia, elevation of blood pressure, and embarrassment of the jugular venous dramage are some other causes which mcrease the risk of postoperative brain oedema In spite of all the precautions there are still unknown causes which can produce cerebral complications in the field of surgery of the hypophysis

Before the intracranial approach was introduced by Cushing ${ }^{2}$ the surgical approach for removal of pitutary tumours was from below through the sphenoidal sinus $\mathbb{A}$ tumour of the hypophysis was successfully removed thus from below first by Schloffer in 1907 This operation was received with enthusiasm by many, such as Oscar Hurch of $V_{1 e n n a}{ }^{3}$ When intracranial suigery became popular, the transsphenoidal route was virtually abandoned and almost forgotten However, this method is still currently employed by well-recognized European neurosurgeons Norman Dott in Edmburgh, Guıt in Parss, ${ }^{4}$ and Norleen in Sweden In our country, no mention is made in the literature that this oper ation was ever performed It was introduced in our hospital by $\mathbb{H}^{2}$ ardy ${ }^{5}$ The transsphenoidal approach to the sella turcica was performed in 8 cases of hypophysectomy for advanced metastatic cancer of the breast and 10 cases of suprasellar tumours

We had the opportunity to carry out the anaesthesia in all of these 18 cases, and, therefore, we beheve it should be of interest to describe the particular problems involved in this operation from the standpoint of anaesthesia

From the Department of Anaesthesia, Notre-Dame Hospital, Montreal 
The age of the patients varied from 18 to 61 The time of surgical procedure itself varied from 20 minutes for simple radioactive hypophysectomy with yttrium implantation to 3 hours for some cases of pituitary tumours There was no operative mortality No major complications arose during the operation or in the immediate postoperative follow-up period From the point of view of the anaesthetist, this operation can be considered in practice as an extracramial procedure All risks of complications usually feared from intracranial operations are eliminated It is a rather benign operation comparable with submucosal resection of the nasal septum or plastic surgery of the nose

The anaesthetic induction was with thiopenthal (2\% per cent) followed by succinylcholine bromide and ventilation for one minute with 100 per cent oxygen, then endotracheal intubation was done with a non-kinking tube Maintenance of anaesthesia was with halothane for 4 cases of our series and methoxyflurane for 3 cases When epmephrine was added to the local anaesthetic, mantenance of anaesthesia was with meperidine and succinylcholine drip for 9 cases and a neuroleptic for 2 cases

The patient is placed in a semi-seated position on the operating table, with the head lying on the special head rest and slightly turned towards the surgeon Since the only incision is done beneath the upper lip in the gingivolabial groove, some blood might get into the mouth Therefore, it is advisable to use an orotracheal tube with an inflated cuff and also to pack the oropharyngeal cavity with a sponge In our department this operation is carried out under radiofluoroscopic control with an image intensifier monitored on a television screen Explosive agents are contraindicated because of the high-voltage currents used Because the patient's head is surrounded by X-ray tube and image intensifier under the drapes, access to it is impossible for accurate observation of respiration and pupillary reflexes We prefer to assist or control the respiration by hand in order to evaluate more accurately the depth of anaesthesia In 2 cases, which were on mechanical control of respination, we had some transitory difficulty

All cases of pitutary tumour removal were uneventful from the anaesthetic point of view at the time of the exturpation In 2 cases of hypophysectomy of the normal pitutary for carcinoma of the breast, the blood pressure fell $20 \mathrm{~mm}$ $\mathrm{Hg}$ in one, and $60 \mathrm{~mm} \mathrm{Hg}$ in the other at the time of the surgical exturpation of the hypophysis, but was promptly iestored to normal by intravenous injection of methoxamine

All cases had received cortisone acetate $100 \mathrm{mg}$ intramuscularly the night before operation, $50 \mathrm{mg}$ the moining of the operation, and were supported with intravenous hydrocortasone $100 \mathrm{mg}$ during the operation

\section{SUMMARY}

Intracranial subfrontal hypophysectomy is a senous procedure associated with some dufficult problems of anaesthesia The most important one is to prevent cerebral oedema caused by retraction of the frontal lobe for a long tume

On the other hand, surgery of the normal or tumoural hypophysis carned out by the transsphenoidal approach appears to be a safe technique that gives rise 
to no serious problems of anaesthesia Some particular points are reported on the basis of our experience in a series of 18 cases

\section{RÉSUMÉ}

L'hypophysectomie par voie intracrânienne sous frontale entraine des problèmes anesthésıques Le plus difficıle a solutıonner est celuı de l'oédème ou de la tuigescence cérébrale

Par voı nasale ou extra-crânıenne (trans-sphénoıdale) le problème du gonflement du cerveau ne se pose plus et les difficultés anesthésıques sont réduites au minımum

Dix-huit patıents opérés par voie nasale (10 pour tumeur de la selle turcique et 8 pour hypophysectomie simple) nous ont permıs ıécemment de préciser la technique anesthésıque, de constater la simplıcité de la méthode et l'excellence des résultats

\section{REFERENCES}

1 Dott, N , Bailey, P \& Cushing, H Brit J Surg 13 311 (1925-26)

2 Cushing, $\mathbb{H}$ Trans Am Surg Assoc 31467 (1913), J A M A 76 172 (1921)

S Hursch, O Wien Med Wschr 6!1519 (1914), TAM A 55772 (1910)

4 Guiot, $\mathrm{G}$, et al Adénomes hypophysaires Paris Masson (1958)

5 HARDY, I L'Exérèse des adénomes hypophysarres par'vole trans-sphénordale L'Union Méd Canada 91933 (1962) 